\title{
Pengaruh Covid-19 Terhadap Kesehatan Mental Masyarakat Di Kota Malang
}

\author{
${ }^{1}$ Wahyu Setyaningrum, ${ }^{2}$ Heylen Amildha Yanuarita \\ ${ }^{1}$ Administrasi Publik, Universitas Kadiri \\ Email Korespondensi: wahyusetyaningrum@unik-kediri.ac.id
}

\begin{abstract}
It is undeniable that the presence of the COVID-19 pandemic has a major impact on public health. Not only from a physical point of view, but also psychological health because of the various problems and anxiety that occurs as a result. This study aims to see and find out how COVID19 affects the mental health of the community, especially in Malang City, East Java. In the research, the writer used descriptive qualitative method assisted by purposive sampling technique. Of course, it is complemented by a simple literature study on various data and documents that already exist and are related to the subject under study. The results of this study show that the COVID-19 pandemic does have an impact on people's mental health, mainly due to high levels of stress due to illness caused by viruses, excessive anxiety, and various other influences.
\end{abstract}

Keywords: The influence of Covid-19, mental health, Malang City

Abstrak. Tidak bisa dipungkiri, kehadiran pandemi COVID-19 membawa pengaruh yang besar terhadap kesehatan masyarakat. Bukan hanya dari segi fisik, namun juga kesehatan psikis sebab berbagai masalah dan kecemasan yang terjadi akibatnya. Penelitian iirini bertujuan untuk melihat dan mencari tahu bagaimana pengaruh COVID-19 terhadap kesehatan mental masyarakat khususnya di kawasan Kota Malang, Jawa Timur. Dalam penelitian, penulis menggunakan metode kualitatif deskriptif dibantu dengan teknik pengambilan sampel purposive sampling. Tentunya dilengkapi dengan studi literatur sederhana pada berbagai data dan dokumen yang sudah ada sebelumnya dan berkaitan dengan bahasan yang diteliti. Adapun hasil dari penelitian ini menunjukan bahwa pandemi COVID-19 memang membawa pengaruh pada kesehatan mental masyarakat, utamanya disebabkan karena tingkat stress yang tinggi baik karena sakit yang diakibatkan oleh virus, kecemasan berlebih, dan berbagai pengaruh lainnya.

\section{Kata kunci: Pengaruh Covid-19, kesehatan mental, Kota Malang}

\section{PENDAHULUAN}

Pengaruh pandemi COVID-19 secara nyata memang terasa oleh masyarakat di seluruh di dunia. Pada pengertiannya, COVID19 atau Corona Virus Disaese 2019 adalah jenis virus baru (Zulva, 2020) yang awalnya ditemukan pada tahun 2019 di Kota Wuhan China, dan belum pernah diidentifikasi menyerang manusia sebelumnya (World Health Organization, 2020). Karena perkembangan dan penyebaran virus yang begitu cepat, WHO pun kemudian menyatakan status COVID-19 sebagai pandemi atau epidemi global sehingga perlu penerapan dan pencegahan penyebaran virus secara masif. Hal ini terbukti dengan diterapkannya beberapa aturan di berbagai negara termasuk di
Indonesia, yakni penggunaan masker, hand sanitizer, disinfektan, cuci tangan yang teratur, dan pemberlakukan pshycal distancing sehingga memicu trending tagar \#dirumahaja di berbagai media sosial.

Kehadiran wabah pandemi COVID-19 tentunya banyak memberikan dampak dan pengaruh yang tidak biasa pada kehidupan masyarakat. Bukan hanya dampak yang terjadi pada kesehatan fisik, namun kondisi psikologis individu dan masyarakat pun ikut terpengaruh juga. Seperti yang dikatakan oleh Brook dkk (2020) bahwa ada beberapa dampak psikologi ketika pandemi yang terjadi dan dirasakan oleh masyarakat yakni gangguan stres pascatrauma (post traumatic stress disorder), kebingungan, kegelisahan, frustasi, ketakutan akan afeksi, 
insomnia, dan merasa diri tidak berdaya. Kondisi yang paling parah adalah kemunculan kasus xenofobial dan juga kasus bunuh diri karena seseorang sangat ketakutan jika dirinya akan terinfeksi oleh virus yang dianggap sangat mengerikan.

Kondisi yang datang dan berubah secara tiba-tiba, akan membuat masyarakat menjadi tidak siap dalam menghadapinya. Selaras dengan pendapat Fitria (2020) dimana kondisi psikologis yang banyak dialami masyarakat khususnya di Indonesia adalah rasa anxiety apabila tertular. Menurut Kartini Kartono (dalam Linda, 2020) menyatakan bahwa anxiety adalah bentuk ketidakberanian ditambah kerisauan terhadap hal-hal yang tidak jelas. Banyak ahli berpendapat bahwa kesehatan fisik dan mental sebenarnya harus dikelola dengan seimbang. Ketika seseorang tidak memiliki mental yang sehat, maka dirinya bisa dikatakan terkena gangguan mental.

Menurut Yustinus Semiun (2006: 9) mengatakan bahwa mental yang tidak sehat adalah mental yang terganggu, yang didefinisikan sebagai gangguan atau penyakit yang bisa menghalangi seseorang untuk hidup sehat seperti yang diinginkan oleh indvidu itu sendiri maupun orang lain. Bentuk dari gangguan mental ini pun tidak terbatas, bisa dimulai dari gangguan emosional, hingga ketidakmampuan menyesuaikan diri.

Ketika seseorang memiliki mental yang tidak sehat, maka kecemasan-kecemasan cenderung akan menguasai dirinya. Apalagi, pada dasarnya semua gangguan kesehatan mental diawali oleh perasaan cemas (anxiety). Menurut Sadock dkk. (dalam Deshinta, 2020) kecemasan adalah respons terhadap situasi tertentu yang mengancam, dan merupakan hal yang normal terjadi. Kecemasan diawali dari adanya situasi yang mengancam sebagai suatu stimulus yang berbahaya (stressor). Pada tingkatan tertentu kecemasan dapat menjadikan seseorang lebih waspada (aware) terhadap suatu ancaman, karena jika ancaman tersebut dinilai tidak membahayakan, maka seseorang tidak akan melakukan pertahanan diri (self defence).
Ketika COVID-19 mulai ditetapkan sebagai pandemik oleh WHO, semua masyarakat merasa panik. Terlebih semua media dan pemberitaan yang secara serentak dipenuhi oleh berita-berita mengerikan tentang virus corona ini. Dari mulai orang-orang yang terinfeksi virus dimana penjalarannya sangat cepat hingga bisa membuat penderita kehilangan nyawa dalam waktu yang sebentar, proses penyebaran virus yang sangat cepat dan melalui kontak langsung, dan pemberitaan mengerikan lainnya. Tak hanya itu, pemberlakuan pshycal distancing pun memicu pengaruh pada kesehatan mental masyarakat. Tingkat stress semakin tinggi, terlebih ketika para perusahaan dan pabrik tutup sehingga harus mem-PHK banyak pegawainya. Hingga rasa bosan yang memicu stress karena masyarakat merasa dikekang dan tidak bisa mengekspresikan diri seperti biasanya (Iqbal: 2020).

Kondisi tersebut sangat bisa memicu kecemasan berlebih pada semua orang karena mereka takut bahwa dirinya akan terjangkit dan mengalami hal mengerikan. Pasalnya, kecemasan ini merupakan suatu kondisi tegang yang berhubungan dengan ketakutan, kekhawatiran, perasaan tidak aman, dan kebutuhan akan kepastian. Kecemasan ini pun merupakan respons terhadap apa saja yang sedang terjadi. Ketika kecemasannya bersifat tidak wajar tentunya akan memberatkan dirinya dan menyebabkan kelumpuhan dalam memberikan keputusan atau melakukan suatu tindakan (Yustinus, 2006: 263).

Di Indonesia sendiri, kekhawatiran dan kecemasan masyarakat sangat tersirat dengan jelas. Terlebih ketika awal-awal kedatangan virus Coron ke Indonesia yang menjadikan berbagai kegiatan lumpuh sementara. Begitu pun di Kota Malang, terhitung sampai saat ini, kasus COVID-19 di kawasan Kota Malang masih terus mengalami kenaikan. Dikutip dari Kompas TV (2020) tercatat sebanyak 2232 pasien yang terkonfirmasi positif korona pada 25 November 2020. Data ini merupakan hasil akumulasi dengan adanya penambahan sebanyak 8 orang dari data sebelumnya, 1 orang tambahan pasien meninggal, dan 7 orang pasien sembuh. Data tersebut tentunya 
membuat Kota Malang masih berada pada zona tidak aman sehingga pembatasan sosial masih dilakukan besar-besaran.

Pada penelitian kali ini, penulis ingin menilik bagaimana pengaruh COVID-19 terhadap kesehatan mental masyarakat khususnya di Kota Malang yang sampai saat ini penambahan kasus tetap terjadi, apa saja faktor yang mempengaruhi perubahan kondisi kesehatan mental, dan bagaimana cara menanggulangi masalah kesehatan mental tersebut di Kota Malang, Jawa Timur.

\section{METODE PENELITIAN}

Metode yang gunakan oleh penulis dalam dalam penelitian kali ini yakni menggunakan metode kualitatif dan studi literatur. Penelitian dengan metode kualitatif dimaksudkan untuk mengkonstruksi realitas dan memahami maknanya dimana dalam penelitian akan sangat memperhatikan proses, peristiwa dan otentisitas (Gumilar, 2005). Sementara studi literatur dijadikan sebagai metode pemerkuat data yang didapatkan ketika penelitian sehingga bisa dipahami maknanya secara maksimal.

Seperti yang diketahui, setiap penelitian pasti memerlukan objek atau subjek yang harus diteliti, sehingga permasalahan yang ada dapat terpecahkan. Populasi dalam penelitian berlaku sebagai objek penelitian, dengan menentukan populasi maka peneliti dapat melakukan pengolahan data. Meskipun begitu, karena adanya keterbatasan penulis dalam menjangkau seluruh populasi yang dalam penelitian ini adalah masyarakat di Kota Malang, maka pengambilan sampel adalah hal tepat. Sampel adalah bagian dari jumlah dan karakteristik yang dimiliki oleh populasi.

Menurut Sugiarto dalam Martono (2010:75) apabila kita tidak mungkin mengamati seluruh anggota populasi yang ada, hal tersebut dapat terjadi jika anggota populasi sangat banyak: pengamatan terhadap seluruh anggota populasi dapat bersifat merusak, menghemat biaya, waktu dan tenaga yang digunakan, serta mampu memberikan suatu informasi yang akurat, lebih menyeluruh dan mendalam (komprehensif).
Untuk mendapatkan sampel yang tepat, tentunya diperlukan metode atau teknik penentuan sampel yang sesuai. Dimana untuk mengumpulkan sampel yang sesuai tersebut penulis memilih untuk menggunakan teknik purposive sampling atau penentuan sampel dengan memperhatikan berbagai pertimbangan tertentu.

Sebab, penelitian ini dilakukan khusus untuk mengkaji bagaimana pengaruh COVID19 pada kesehatan mental masyarakat di Kota Malang. Maka pengambilan data pun dilakukan dengan melakukan wawancara responden serta observasi di kawasan Kota Malang. Sehingga data yang diambil merupakan responden yang benar-benar mengetahui dan berkesinambungan dengan penelitian.

Adapun pihak-pihak atau sampel yang dijadikan penelitian yakni masyarakat di Kota Malang. Dimana penulis melakukan wawancara mengenai pendapat, pandangan, dan pengalaman responden terkait kondisi mentalnya selama pandemi. Karena adanya keterbatasan penulis dan juga sesuai dengan anjuran pemerintah tentang pembatasan sosial, terlebih kondisi pandemi akibat COVID-19 belum juga normal, maka proses pencarian data dilakukan secara daring atau online melalui media sosial seperti WhatsApp, Telegram, Instagram dan Zoom.

Meskipun begitu, proses penelitian tetap memandang realitas yang merupakan hasil rekonstruksi oleh individu yang terlibat dalam situasi sosial dan penulis menjalin interaksi secara intens dengan realitas yang diteliti (Wahidmurni, 2017). Nantinya, data hasil wawancara diolah dan dikaji, serta ditelaah kembali dengan melakukan penggalian informasi berdasarkan beberapa sumber tertulis seperti buku-buku, artikel, jurnal, majalah, serta dokumen sesuai dengan permasalahan yang dikaji sehingga dapat memperkuat data hasil penelitian.

\section{HASIL DAN PEMBAHASAN \\ 1. Kesehatan Mental}


Kesehatan mental memiliki peranan yang cukup penting untuk memaksimalkan kesehatan setiap individu. Meskipun begitu, seseorang yang punya kesehatan mental baik belum tentu terbebas dari berbagai gangguan mental yang mungkin terjadi. Menurut Siti Nurjanah (2020) Gangguan mental emosional merupakan suatu keadaan yang mengindikasikan individu yang mengalami suatu perubahan emosional yang dapat berkembang menjadi keadaan patologis apabila terus berlanjut. Orang yang memiliki kesehatan mental yang baik sekalipun, pada dasarnya tidak bisa terlepas dari kecemasan dan juga perasaan bersalah.

Meskipun begitu, orang yang punya kesehatan mental baik tidak akan dikendalikan oleh kecemasan dan rasa bersalah bersalah tersebut. Sehingga dirinya mampu menyelesaikan segala masalah dan hambatan dengan penuh keyakinan serta bisa memecahkan masalah tersebut tanpa hal lain yang bisa menganggu sttuktur dirinya sendiri (Yustinus: 2006).

Ketika seseorang memiliki kesehatan mental yang buruk, maka kondisinya adalah banyak kecemasan yang menghantui dirinya dan mengendalikan dirinya. Penyebab terganggunya kesehatan mental seseorang tentu bisa terdiri dari banyak faktor.

\section{Faktor yang Mempengaruhi Kondisi Mental Sejak Pandemi}

Banyaknya orang yang mengalami permasalahan kesehatan mental akibat pandemi Covid-19 sangat bisa dipahami mengingat pandemi Covid-19 merupakan sumber stres baru bagi masyarakat dunia saat ini. Secara global, terdapat empat faktor risiko utama depresi 14 yang muncul akibat pandemi Covid-19 (Thakur dan Jain (dalam Sulis, 2020)).

Pertama, faktor jarak dan isolasi sosial. Ketakutan akan Covid-19 menciptakan tekanan emosional yang serius. Rasa keterasingan akibat adanya perintah jaga jarak telah mengganggu kehidupan banyak orang dan mempengaruhi kondisi kesehatan mental mereka, seperti depresi dan bunuh diri. Mengacu pada beberapa kasus yang terjadi di
India, Amerika Serikat, Saudi Arabia, dan Inggris, isolasi selama pandemi Covid-19 kemungkinan berkontribusi terhadap bunuh diri.

Kedua, resesi ekonomi akibat Covid-19. Seperti yang diketahui, pandemi Covid-19 telah memicu krisis ekonomi global yang kemungkinan akan meningkatkan risiko bunuh diri terkait dengan pengangguran dan tekanan ekonomi. Bukan rahasia, ketika pembatasan sosial berskala besar dilakukan, banyak perusahaan yang mulai menutup pabrik atau perusahannya yang kemudian mem-PHK karyawan mereka. Tentu kondisi tersebut akan memicu perasaan putus asa, kecewa, cemas yang berlebihan, perasaan akan ketidakpastian, hingga perasaan tidak berharga yang bisa memicu seseorang berniat untuk bunuh diri.

Faktor lainnya adalah pada masalah sosial dan budaya masyarakat ketika pemberlakuan pshycal distancing. Seperti misalnya para remaja yang biasanya menghabiskan waktu libur dengan bermain bersama temannya, selama pandemi dipaksa harus diam di rumah. Tentunya jika hal tersebut terjadi secara terus-menerus akan berdampak pada rasa bosan yang memicu stress orang tersebut.

Menurut Deshinta (2020), ada beberapa golongan masyarakat yang sangat rentan terkena gangguan mental selama pandemi. Kondisi rentan ini adalah seperti perempuan, anak dan remaja, serta lansia. Kondisi tersebut perlu dijadikan perhatian mengingat perempuan memegang peran yang sangat penting dalam mengelola rumah tangga. Anakanak dan remaja pun tidak luput dari dampak kebijakan pembatasan penyebaran virus melalui sistem pembalajaran jarak jauh. Ruang gerak yang terbatas dan minimnya interaksi dengan teman sebaya selama masa pandemi dapat berpengaruh terhadap kesehatan jiwa mereka.

Remaja yang sejatinya merupakan kelompok usia paling rentan akan stress dan kecemasan kini dihadapkan kepada sebuah polemik baru akibat wabah COVID-19 yang akan semakin meningkatkan resiko terjadinya stress dan kecemasan. Kegiatan yang biasanya dapat mereka lakukan dengan wajar kini 
menjadi terbatas, akses sosial kepada individu dan komunitas juga tidak dapat mereka lakukan seperti biasanya, hal inilah yang dapat menjadi tekanan-tekanan baru kepada kelompok rentan ini selama Jurnal menghadapi wabah COVID-19.

Begitu juga dengan kelompok lansia dimana kerentanan disebabkan oleh proses degeneratif yang menyebabkan menurunnya imunitas tubuh sehingga lansia rentan terinfeksi penyakit, termasuk virus corona. Di tengah kondisi pandemi yang penuh ketidakpastian, lansia mudah dihinggapi perasaan cemas berlebihan yang kemudian berpengaruh terhadap kondisi kesehatan fisik. Situasi yang demikian kompleks dan penuh tekanan secara psikologi dari setiap kelompok usia membutuhkan perhatian dan penanganan yang cepat sehingga tidak menjadi ganguan jiwa yang lebih serius. Kelompok rentan yang disebutkan di atas adalah potret umum kondisi masyarakat saat ini.

Menurut World Health Organization (WHO) (2019), stres yang muncul selama masa pandemi COVID-19 dapat berupa: (a). Ketakutan dan kecemasan mengenai kesehatan diri maupun kesehatan orang lain yang disayangi (b). Perubahan pola tidur dan/atau pola makan (c). Sulit tidur dan konsentrasi (d). Memperparah kondisi fisik seseorang yang memang memiliki riwayat penyakit kronis dan/atau gangguan psikologis atau menggunakan obat-obatan (drugs).

\section{Pengaruh COVID-19 Terhadap Kesehatan Masyarakat di Kota Malang}

COVID-19 pada realitasnya tidak hanya memberikan pengaruh pada kesehatan fisik masyarakat saja, namun juga memberikan pengaruh pada aspek kehidupan lainnya. Pengaruh yang cukup terasa terjadi pada kondisi kesehatan mental masyarakat yang terdampak pandemi. Kondisi kehidupan semenjak adanya pandemi COVID-19 memang banyak membuat kehidupan masyarakat jadi berbeda. Perubahan yang terjadi secara tiba-tiba, membuat masyarakat sulit beradaptasi dan menyebabkan stress hingga trauma. Banyaknya pemberitaan dan informasi mengenai penyebaran COVID-19 yang terkesan menakutkan, membuat masyarakat merasa cemas dan khawatir. Begitu halnya di Kota Malang, Jawa Timur.

Berdasarkan penelitian yang dilakukan oleh penulis mengindikasikan sebuah hasil dimana COVID-19 memang memiliki banyak pengaruh terhadap kesehatan mental masyarakat di Kota Malang. Pengambilan data dan hasil penelitian dilakukan melalui proses wawancara dan pendekatan mendalam pada sampel yang telah ditentukan sebelumnya. Adapun beberapa pertanyaan utama dalam wawancara yang ditanyakan penulis pada responden, adalah sebagai berikut:

- Ketika penyebaran COVID-19 di Indonesia mulai massif terjadi, bagaimana perasaan yang Bapak/Ibu rasakan?

- Bagaimana kondisi Bapak/Ibu ketika pembatasan sosial terjadi khususnya dari segi psikologis?

- Hal apa saja yang membuat Bapak/Ibu merasakan kecemasan?

- Apakah Bapak/Ibu merasa nyaman dengan kondisi tersebut?

Berdasarkan pertanyaan-pertanyaan tersebut, penulis menemukan beberapa jawaban dari masyarakat di Kota Malang. Jawaban-jawaban tersebut dimulai dari adanya rasa kecemasan, ketakutan, dan kekhawatiran masyarakat terkena virus yang dianggap sangat berbahaya dan mematikan. Kebanyakan dari masyarakat melakukan pembatasan diri sendiri, mengurangi kontak fisik, hingga mengisolasi dan mengasingkan diri sendiri di rumah. Meskipun pembatasan sosial dan proses isolasi mandiri dilakukan berdasarkan keinginan sendiri, namun setelah beberapa waktu kebanyakan masyarakat pun merasa jengah.

Pemberlakukan phsycal distancing, pembatasan sosial, dan perubahan tingkah laku akibat kebijakan protokol kesehatan mampu mengubah tatanan kehidupan masyarakat di Kota Malang. Banyak masyarakat yang harus membatasi komunikasi langsung, hingga membatasi diri untuk mengaktualisasikan diri. Padahal, menurut Yustinus (2006), aktualisasi diri adalah salah satu cara tepat untuk membantu memperbaik kesehatan mental. 
Tak hanya itu, kebanyakan responden dalam penelitian pun menjawab bahwa semakin lama, kekhawatiran akan COVID-19 berkurang. Namun, kekhawatiran dan kecemasan bermetamorfosis pada ketakutan akan kekurangan sumber ekonomi, sumber penghasilan, yang mana bisa menghambat dan mengganggu stabilitas kehidupan setiap keluarga.

Sejalan dengan informasi yang dikutip dari jatimtimes.com, Selama pandemi covid19, sebagian besar karyawan di Kota Malang dirumahkan. Setidaknya ada empat ribu pekerja yang dirumahkan dan dilakukan Pemutusan Hubungan Kerja (PHK). Kepala Dinas Ketenagakerjaan, Penanaman Modal dan Pelayanan Terpadu Satu Pintu (DisnakerPMPTSP) Kota Malang, Erik Setyo Santoso menyampaikan, selama pandemi covid-19, setiap perusahaan melaporkan jika mereka telah merumahkan para karyawan. Berdasarkan data terkahir, total ada 4.686 pekerja yang dirumahkan dan dilakukan Pemutusan Hubungan Kerja (PHK). Dengan rincian, 4.239 pekerja yang dirumahkan, terdiri dari 2.014 warga Kota Malang dan 2.225 warga luar Kota Malang.

Adanya PHK besar-besaran inilah yang kemudian menjadi faktor kecemasan dan stress masyarakat di Kota Malang sehingga menggangu kondisi psikologis dan kesehatan mental masyarakat. Begitu pun ketika sebagian pegawai melakukan WFH (work from home) dimana seorang pegawai yang pada masa pandemi ini melakukan kerja dari rumah (work from home) akan melakukan rasionalisasi bahwa memiliki kinerja yang kurang optimal. Bekerja di rumah di masa pandemi bukan sekedar pindah ruang kerja. Rasionalisasi ini bukan untuk orang lain, tapi untuk dirinya sendiri, sebagai upaya menjaga kesehatan mental diri sehingga tidak menimbulkan frustasi, rasa bersalah, dan perasaan tidak berdaya (Salma, 2020).

\section{KESIMPULAN}

Berdasarkan analisis dan kajian yang telah dilakukan penulis, maka dapat ditarik kesimpulan bahwa COVID-19 membawa pengaruh terhadap kesehatan mental masyarakat di Kota Malang, Jawa Timur. Adapun gangguan mental yang terjadi yakni berupa kecemasan dan ketakutan akan terinfeksi virus khususnya pada awal-awal kemunculan COVID-19, yang kemudian berubah menjadi kecemasan karena ketakutan dan kehilangan pekerjaan oleh banyak masyarakat. Kecemasan ini pun memicu adanya kenaikan tingkat stress dan rasa putus asa yang dirasakan. Meskipun begitu, tingkat gangguan mental yang dialami oleh masyarakat Kota Malang tidak terlalu parah jika dibandingkan dengan negara lain berdasarkan beberapa kajian sebelumnya.

\section{SARAN}

Melihat pada terdapatnya pengaruh COVID19 terhadap kesehatan masyarakat di Kota Malang, maka perlu dilakukan pemulihan psikologis masyarakat. Pada dasarnya, gangguan kesehatan mental diakibatkan karena rasa takut, khawatir dan cemas yang berlebih. Untuk itu, masyarakat perlu membatasi dirinya agar tidak terlalu dibelenggu oleh kecemasan. Pun, pihak pemerintah atau lembaga-lembaga lain yang punya wewenang, sebaiknya bisa memberikan langkah preventif guna mengatasi permasalahan mental yang terjadi akibat pandemi virus corona ini.

\section{DAFTAR PUSTAKA:}

Martono, N. (2010). Metode Penelitian Kuantitatif. Jakarta: Rajawali Pers

Semiun, Yustinus. (2006). Kesehatan Mental 3. Yogyakarta: Penerbit Kanisius

Sugiyono. (2014). Metode Penelitian

Pendidikan Pendekatan Kuantitatif, Kualitatif, dan R\&D. Bandung: Alfabeta.

\section{Jurnal:}

Zulva, T. N. I. (2020). Covid-19 Dan Kecenderungan Psikosomatis. J. Chem. Inf. Model, 1-4

Organization, W. H. (2020). Mental health and psychosocial considerations during the COVID-19 outbreak, 18 March 2020: World Health Organization. Google Scholar 
Brooks, K.S. (2020). The Psychological Impact of Quarantine and How to Reduce It: Rapid Review of the Evidence. Lancet, 395, pp. 912-920.

Fitria, L. (2020). Cognitive Behavior Therapy Counseling Untuk Mengatasi Anxiety Dalam Masa Pandemi Covid-19. ALIRSYAD, 10(1).

Linda. (2020). Kecemasan Remaja Pada Masa Pandemi Covid -19. Jurnal Educatio. 6 (1). 1-4

Iqbal. (2020). Deteksi Dini Kesehatan Mental Akibat Pandemi Covid-19 Pada Unnes Sex Care Community Melalui Metode Self Reporting Questionnaire. 3 (1). 20-24

Deshinta. (2020). Kesehatan Mental Masyarakat: Mengelola Kecemasan di Tengah Pandemi Covid-19. Jurnal Kependudukan Indonesia. Edisi Khusus Demografi dan COVID-19. 69-74

Wahidmurni. (2017). Pemaparan Metode Penelitian Kualitatif. Dosen Fakultas Ilmu Tarbiyah dan Keguruan UIN Maulana Malik Ibrahim Malang. Available from: http://repository.uinmalang.ac.id/1984/2/1984.pdf

Nurjanah, Siti. (2020). Gangguan Mental Emosional Pada Klien Pandemi Covid 19 di Rumah Karantina. Jurnal Ilmu Keperawatan Jiwa. 3 (3). 329-334

Sulis. (2020). Permasalahan Kesehatan Mental Akibat Pandemi Covid-19. Pusat Penelitian Badan Keahlian DPR RI. 11 (15). 13-18

Salma. (2020). Analisis Pengaruh Tingkat Kematian Akibat Covid-19 Terhadap Kesehatan Mental Masyarakat di Indonesia. Focus: Jurnal Pekerjaan Sosial. 3 (1). 16-28

\section{Website:}

Jatim News. (2020). Masa Recovery Karyawan Dirumahkan di Kota Malang Kembali Ditarik Perusahaan. Retrieved November 25, 2020. Interact website https://jatimtimes.com/baca/225352/2 $\underline{0201004 / 133800 / \text { masa-recovery- }}$

Jurnal Ilmu Sosial dan Pendidikan karyawan-dirumahkan-di-kotamalang-kembali-ditarik-perusahaan

Kompas TV. Data COVID-19 Kota Malang 25 November 2020. Retrieved November 25, 2020. Interact website: https://www.kompas.tv/article/126277 /data-covid-19-kota-malang-25november-2020 